Жила М. І., кандидат ветеринарних наук,

Михалюк О. В., Бассараб В. П., Максимович О. А., співробімники

Державний науково-дослідний контрольний інститут ветеринарних препаратів та кормових добавок, м. Львів

\title{
ВПЛИВ ПРОБІОТИЧНОГО ПРЕПАРАТУ «ПРОБІОН» НА ГЕМАТОЛОГІЧНІ ТА ОКРЕМІ ІМУНОЛОГІЧНІ ПОКАЗНИКИ КУРЧАТ-БРОЙЛЕРІВ
}

\section{Рецензент - доктор біологічних наук, професор О. Г. Малик}

\begin{tabular}{|} 
Представлені дані щодо впливу препарату \\
«Пробіон» на динаміку росту, а також гематоло- \\
гічні та імунологічні показники курчат-бройлерів. \\
Встановлено, щуо у курчат, які отримували препа- \\
рат «Пробіон», упродовж усього періоду вирощу- \\
вання інтенсивніше зростала середня жива маса \\
та добові прирости. Встановлено тенденцію до \\
підвищення вмісту гемоглобіну, зростання кілько- \\
сті лейкоитів і фагоцитарної активності псев- \\
доеозинофілів. Найбільшу відмінність показників \\
встановлено в курчат, яким згодовували пробіотик \\
«робіон» у дозі 1 г/кг корму.
\end{tabular}

Ключові слова: курчата-бройлери, пробіотики, гематологічні показники, неспецифічна резистентність.

Постановка проблеми. Пробіотики - бактеріальні препарати, що виявляють позитивний вплив на ендогенну мікрофлору, широко використовуються у ветеринарній медицині як альтернатива антибіотикам.

Пробіотики - це мікроорганізми чи їх метаболіти, що заселяють кишковий тракт господаря для встановлення або підтримки нормального балансу мікрофлори кишечника $[1,6]$.

Аналіз останніх досліджень і публікацій, у яких започатковано розв'язання проблеми. Пробіотичні метаболіти забезпечують макроорганізм біологічно активними речовинами, пригнічують патогенну та умовнопатогенну мікрофлору, збільшують засвоєння кормів, а також приріст живої маси [2].

Пробіотики не мають протипоказань у використанні, вікових чи фізіологічних обмежень, екологічно безпечні, не проявляють комулятивних властивостей [6-8].

Метою наших досліджень було вивчення гематологічних та окремих імунологічних показників курчат-бройлерів у процесі застосування нового пробіотичного препарату «Пробіон».

Завдання: порівняти ефективність «Пробіон» 3 іншим пробіотичним препаратом.
Матеріали і методи дослідження. Дослід проводився в приватному господарстві КТ «Его» Жовківського району Львівської області на курчатах-бройлерах кросу «Kobb-500», однодобового віку, сформованих у 4 групи (по 300 голів у кожній).

Препарати застосовували 3 кормом, упродовж усього періоду вирощування в таких дозах:

І група отримувала пробіотик «Пробіон» у дозі 1 г/кг,

II група - «Пробіон» у дозі 0,5 г/кг;

III група - пробіотик-аналог «Біоплюс 2Б» у дозі 0,4 г/кг,

IV група (К) була контролем.

Основу досліджуваних пробіотиків складають спороутворюючі аеробні бактерії B. Subtilis.

Комбікорм згодовували згідно 3 нормами, рекомендованими для кросу «Kobb-500», вакцинацію курчат проводили проти інфекційного бронхіту, хвороби Гамборо та хвороби Ньюкасла. Щоденно спостерігали за клінічним станом птиці та проводили щотижневе зважування з визначенням середньодобових приростів живої маси курчат. Забір матеріалу для досліджень проводили на 15-у, 30-у і 43-ю добу досліду.

У гепаринізованій крові визначали концентрацію гемоглобіну, гематокрит, число еритроцитів, лейкоцитів, лейкоформулу, фагоцитарну активність псевдоеозинофілів (ФАН) та фагоцитарний індекс (ФI) [3, 4].

Отримані результати обробляли статистично за допомогою програми STATISTICA, з урахуванням критерію Стьюдента.

Результати дослідження. Встановлено, що у птиці дослідних і контрольної груп протягом усього досліду не відмічалося відхилень від норми загального стану, поведінки й апетиту.

Слід зазначити, що протягом досліду спостерігали більш інтенсивне зростання як середньої живої маси тіла, так і середньодобових приростів у курчат дослідних груп (табл. 1). 
ВЕТЕРИНАРНА МЕДИЦИНА

1. Прирости маси тіла курчат-бройлерів у разі застосування пробіотиків $(M \pm m, n=50)$

\begin{tabular}{|c|c|c|c|c|}
\hline Показник & І група & II група & III група & K \\
\hline $\begin{array}{c}\text { Маса тіла курчат } \\
\text { на початку досліду, г }\end{array}$ & $38,75 \pm 0,78$ & $38,16 \pm 0,98$ & $37,83 \pm 0,96$ & $39,33 \pm 0,71$ \\
\hline $\begin{array}{c}\text { Маса тіла курчат } \\
\text { на 15-у добу досліду, г }\end{array}$ & $401,06 \pm 4,88$ & $399,2 \pm 7,40$ & $390,93 \pm 5,26$ & $394,16 \pm 5,28$ \\
\hline $\begin{array}{c}\text { Маса тіла курчат } \\
\text { на 30-у добу досліду, г }\end{array}$ & $1718,83 \pm 36,87$ & $1690,15 \pm 47,88$ & $1499,5 \pm 33,55$ & $1447,46 \pm 33,87$ \\
\hline $\begin{array}{c}\text { Маса тіла курчат } \\
\text { на 43-ю добу досліду, г }\end{array}$ & $2426,92 \pm 34,43$ & $2411,15 \pm 43,13$ & $2193,38 \pm 47,17$ & $2178,46 \pm 43,78$ \\
\hline Маса патраної тушки, г & $1623 \pm 16,6$ & $1593 \pm 18,2$ & $1368 \pm 14,1$ & $1348 \pm 16,7$ \\
\hline Забійний вихід, \% & 66,9 & 66,1 & 62,4 & 61,9 \\
\hline Середньодобовий приріст, г & 56,9 & 56,5 & 51,3 & 50,9 \\
\hline $\begin{array}{c}\text { Затрати корму } \\
\text { за дослід, г/гол. }\end{array}$ & 4253 & 4310 & 4417 & 4433 \\
\hline $\begin{array}{c}\text { Затрати корму } \\
\text { на 1 кг приросту, кг }\end{array}$ & 1,78 & 1,82 & 2,05 & 2,07 \\
\hline
\end{tabular}

Було встановлено, що використання пробіотика сприяє кращому засвоєнню комбікорму і збільшенню маси тіла, в порівнянні $з$ контролем. Збереженість курчат-бройлерів I групи перевищувала аналогічний показник у контрольній групі на 6,0 \%, II групі - на 5,3\%, III групі - 3,7 \%. Як видно $з$ даних табл. 1, затрати корму на кінець дослідного періоду були меншими в I групі курей на 180 г/голову, у II групі - на 123,3 г/голову та у III групі - на 16,7 г/голову порівняно 3 контролем. Маса тіла курчат-бройлерів наприкінці досліду (43-я доба) вирощування була вищою в
I групі на 248,46 у II і III групах, відповідно, на 232,69 г і 14,92 г порівняно з контролем. За середньодобовими приростами I і II дослідні групи випереджали контроль на 6,0 г і 5,6 г відповідно.

У ході дослідження впливу препарату «Пробіон» на гематологічні показники встановлено тенденцію до підвищення вмісту гемоглобіну на 30-у добу досліду в усіх дослідних групах: у порівнянні з 15-ю добою, в I групі концентрація гемоглобіну збільшилась у 1,34 разу, в II групі в 1,49 разу, III - у 1,37 разу (табл. 2).

\section{2. Гематологічні показники крові курей-бройлерів за застосування пробіотиків $(M \pm m, n=12)$}

\begin{tabular}{|c|c|c|c|c|}
\hline \multirow{2}{*}{ Показник } & \multirow{2}{*}{ Групи } & \multicolumn{3}{|c|}{ Час проведення досліду (доба) } \\
\cline { 2 - 5 } & 1 & 15 & 30 & 43 \\
\hline \multirow{4}{*}{ Гемоглобін, г/л } & 2 & $81,8 \pm 4,0^{*}$ & $110,1 \pm 7,3^{\circ}$ & $102,7 \pm 4,2^{*}$ \\
\cline { 2 - 5 } & 3 & $81,8 \pm 3,1^{*}$ & $112,2 \pm 3,9^{\circ}$ & $101,5 \pm 5,5^{*}$ \\
\cline { 2 - 5 } & $\mathrm{K}$ & $87,1 \pm 4,3$ & $113,8 \pm 5,6^{\circ}$ & $109,2 \pm 5,0$ \\
\hline \multirow{3}{*}{ Еритроцити, Т/л } & 1 & $79.6 \pm 3.5$ & $106,7 \pm 3,3^{\circ}$ & $100,1 \pm 6,0$ \\
\cline { 2 - 5 } & 2 & $2,3 \pm 0,2$ & $2,9 \pm 0,1$ & $3,5 \pm 0,2^{*}$ \\
\cline { 2 - 5 } & 3 & $2,0 \pm 0,1^{*}$ & $3,5 \pm 0,1^{* 0}$ & $3,5 \pm 0,2^{*}$ \\
\cline { 2 - 5 } & $\mathrm{K}$ & $1,1 \pm 0,1^{*}$ & $3,4 \pm 0,1^{* 0}$ & $3,5 \pm 0,5^{*}$ \\
\hline \multirow{3}{*}{ Гематокрит, \% } & 1 & $23,03 \pm 0,9$ & $3,0 \pm 0,1$ & $3,0 \pm 0,1$ \\
\cline { 2 - 5 } & 2 & $27,33 \pm 1,02$ & $25,2 \pm 0,85$ & $28,25 \pm 0,67$ \\
\cline { 2 - 5 } & 3 & $23,0 \pm 0,71$ & $26,5 \pm 0,94$ & $27,50 \pm 0,87$ \\
\cline { 2 - 5 } & $\mathrm{K}$ & $23,86 \pm 1,26$ & $25,57 \pm 0,78$ & $29,14 \pm 0,88$ \\
\hline \multirow{3}{*}{ Лейкоцити, Г/л } & 1 & $23,9 \pm 1,3$ & $29,8 \pm 1,2$ & $42,7 \pm 2,0^{* 0}$ \\
\cline { 2 - 5 } & 2 & $30,0 \pm 1,6$ & $29,1 \pm 1,6$ & $40,0 \pm 2,2^{\circ}$ \\
\cline { 2 - 5 } & 3 & $28,0 \pm 1,4$ & $31,6 \pm 1,5$ & $39,7 \pm 2,4^{\circ}$ \\
\hline
\end{tabular}

Примітка. Тут і надалі: ${ }^{*}-\mathrm{p} \leq 0,05$ порівняно до контролю, ${ }^{\circ}-\mathrm{p} \leq 0,05$ порівняно до попереднього визначення 
Підвищення вмісту гемоглобіну має позитивне значення, 3 огляду на інтенсифікацію процесів забезпечення киснем основних систем життєдіяльності організму, крім того відмічалося вірогідне зростання кількості лейкоцитів у всіх дослідних тварин, починаючи 3 15-ї доби й до закінчення досліду на 43-ю добу застосування. В I групі на 30-у добу кількість лейкоцитів зросла в 1,24 разу, порівняно 3 15-ю добою, і в 1,9 разу на 43-ю добу. Отже, «Пробіон» стимулює лейкоцитопоез у курей дослідної групи. Показники гематокриту та лейкоцитарної формули досліджуваних груп курчат знаходились у вікових фізіологічних межах для даного виду птиці.

У ході аналізу лейкоцитарної формули спостерігали збільшення відносного числа лімфоцитів у курчат дослідних груп порівняно з контро- лем, особливо на 15-у і 43-ю доби досліду, а також достовірно нижчим був вміст еозинофілів у дослідних груп курчат відносно контролю на 15-у добу досліду (табл. 3).

Одним із основних механізмів неспецифічної резистентності організму $є$ фагоцитарна активність мікро- та макрофагів. У птиці в процесі фагоцитозу активно беруть участь псевдоеозинофіли, здатні до амебовидного руху $[4,8]$. Як видно 3 даних таблиці 4, фагоцитарна активність псевдоеозинофілів (ФАН) зростала у всіх дослідних групах на 30-у і 43-ю доби застосування препарату. Однак достовірне підвищення було в III групі: на 24 \% (30-а доба) і на 28 \% (43-а доба). Спостерігалася також тенденція до збільшення фагоцитарного індексу в дослідних групах курчат на 30-у та 43-ю добу спостереження.

3. Лейкоцитарна формула крові курчат-бройлерів у разі застосування пробіотиків $(M \pm m, n=12)$

\begin{tabular}{|c|c|c|c|c|}
\hline \multirow{2}{*}{ Показник } & \multirow{2}{*}{ Групи } & \multicolumn{3}{|c|}{ Час проведення досліду (доба) } \\
\hline & & 15 & 30 & 43 \\
\hline \multirow{4}{*}{ Базофіли, \% } & I & $0,8 \pm 0,5$ & $1,0 \pm 0,4$ & $0,4 \pm 0,4$ \\
\hline & II & $0,8 \pm 0,4$ & $0,8 \pm 0,4$ & 0 \\
\hline & III & $0,4 \pm 0,2$ & $0,4 \pm 0,2$ & $0,6 \pm 0,4$ \\
\hline & $\mathrm{K}$ & $1,0 \pm 0,4$ & $0,8 \pm 0,5$ & $0,6 \pm 0,4$ \\
\hline \multirow{4}{*}{ Еозинофіли, \% } & $\mathrm{I}$ & $2,6 \pm 0,6^{*}$ & $4,4 \pm 0,7$ & $4,4 \pm 0,7$ \\
\hline & II & $2,6 \pm 0,4 *$ & $3,6 \pm 0,5$ & $4,8 \pm 0,8$ \\
\hline & III & $2,8 \pm 0,5^{*}$ & $4,2 \pm 0,7$ & $4,8 \pm 0,5$ \\
\hline & $\mathrm{K}$ & $5,2 \pm 0,5$ & $5,2 \pm 0,5$ & $5,2 \pm 0,5$ \\
\hline \multirow{4}{*}{ Псевдоеозинофіли, \% } & $\mathrm{I}$ & $36,6 \pm 1,6$ & $34,0 \pm 1,4$ & $26,8 \pm 2,4$ \\
\hline & II & $39,2 \pm 0,9$ & $33,8 \pm 1,7$ & $28,0 \pm 1,4 *$ \\
\hline & III & $40,0 \pm 2,1$ & $35 \pm 0,6$ & $30,4 \pm 0,7$ \\
\hline & $\mathrm{K}$ & $39,6 \pm 1,5$ & $30,8 \pm 1,8$ & $32,8 \pm 1,0$ \\
\hline \multirow{4}{*}{ Лімфоцити, \% } & I & $53,6 \pm 1,7^{*}$ & $55 \pm 0,4$ & $61,2 \pm 3,0$ \\
\hline & II & $50,0 \pm 1,4$ & $56 \pm 1,6$ & $63,2 \pm 2,1^{*}$ \\
\hline & III & $49,2 \pm 1,9$ & $54,2 \pm 1,2$ & $58,4 \pm 1,3$ \\
\hline & $\mathrm{K}$ & $46,0 \pm 1,7$ & $56,8 \pm 1,6$ & $56,0 \pm 1,1$ \\
\hline \multirow{4}{*}{ Моноцити, \% } & $\mathrm{I}$ & $6,4 \pm 0,7$ & $5,8 \pm 0,7$ & $7,2 \pm 0,5$ \\
\hline & II & $7,4 \pm 1,2$ & $5,8 \pm 0,5$ & $4,0 \pm 0,6$ \\
\hline & III & $7,6 \pm 0,8$ & $6,2 \pm 0,7$ & $5,8 \pm 0,7$ \\
\hline & $\mathrm{K}$ & $8,2 \pm 0,5$ & $6,4 \pm 0,7$ & $5,8 \pm 0,7$ \\
\hline
\end{tabular}

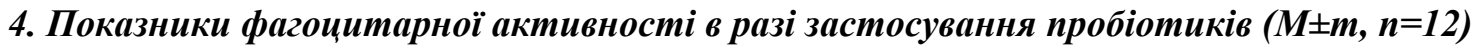

\begin{tabular}{|c|c|c|c|c|}
\hline \multirow{2}{*}{ Показник } & \multirow{2}{*}{ Група } & \multicolumn{3}{|c|}{ Час проведення досліду (доба) } \\
\cline { 2 - 5 } & & 15 & 30 & 43 \\
\hline \multirow{3}{*}{ ФАН, \% } & I & $19,4 \pm 1,1$ & $22,1 \pm 1,0$ & $20,9 \pm 0,5$ \\
\cline { 2 - 5 } & II & $17,4 \pm 0,9$ & $22,1 \pm 0,8$ & $18,5 \pm 0,9$ \\
\cline { 2 - 5 } & III & $18,2 \pm 1,2$ & $22,6 \pm 1,0^{*}$ & $23,3 \pm 1,3^{*}$ \\
\cline { 2 - 5 } & K & $18,0 \pm 1,4$ & $19,0 \pm 0,7$ & $18,8 \pm 1,1$ \\
\hline \multirow{3}{*}{ ФІ, мт/нейтр. } & I & $10,2 \pm 0,8$ & $12,0 \pm 0,9$ & $11,8 \pm 1,1$ \\
\cline { 2 - 5 } & II & $9,9 \pm 0,6$ & $11,8 \pm 1,1$ & $11,1 \pm 0,7$ \\
\cline { 2 - 5 } & III & $12,2 \pm 0,9$ & $10,3 \pm 0,4$ & $13,0 \pm 0,5$ \\
\cline { 2 - 5 } & K & $10,4 \pm 1,0$ & $10,7 \pm 0,6$ & $10,0 \pm 0,9$ \\
\hline
\end{tabular}


Висновок. За результатами експериментальних досліджень встановлено, що препарат «Пробіон» позитивно впливає на організм, інтенсифікуючи окремі ланки метаболізму, функціональний стан кровотворної та імунної систем, забезпечуючи неспецифічну основу всіх адаптивних реакцій організму. Це підтверджується збільшенням середньої маси та середньодобових приростів, а також підвищенням вмісту гемоглобіну,

\section{БІБЛІОГРАФІЯ}

1. Акименко Л. Пробіотики у ветеринарній медицині / Л. Акименко // Ветеринарна медицина. 2005. - № 2. - C. 37-38.

2. Бабина М. П. Коррекция иммунного статуса и повышение продуктивности цыплят-бройлеров пробиотиками //Актуальн. пробл. интенсив. развития животноводства. - Горки, 1998. - С. 294 299.

3. Влізло В. В. Фізіолого-біохімічні методи досліджень у біології, тваринництві та ветеринарній медицині / В.В.Влізло, Р. С. Федорук, I. А. Макар [та ін.] - Львів, 2004. - 40 с.

4. Комплексна оцінка впливу ветеринарних препаратів на морфофункціональний стан імунної системи: Методичні рекомендації / І. Я. Коцюмбас, Г. І. Коцюмбас, Є М. Голубій [та ін.]. - зростанням кількості лейкоцитів, фагоцитарної активності псевдоеозинофілів та фагоцитарного індексу. До того ж найбільшу відмінність показників встановлено у курчат, яким згодовували пробіотик «Пробіон» у дозі 1 г/кг корму.

Перспективи подальших досліджень: вивчення впливу пробіотика «Пробіон» на морфофункціональний стан центральних і периферійних органів імунної системи птиці.

Львів. $-2009 .-63$ с.

5. Коптєв В. Кормові пробіотики як здорова альтернатива антибіотикам // Здоров'я тварин і ліки, 2011, №1. - C. 15-16.

6. Кориунов В. М. Влияние пробиотиков и биотерапевтических препаратов на иммунную систему организма-хозяина / В. М. Коршунов, Н. Н. Володин, С. А. Агафонова [и др.] // Педиатрия. - 2002. - № 5. - С. 92-100.

7. Литвин В. П. Особливості застосування пробіотиків у ветеринарній медицині / В. П. Литвин, В. В. Поліщук [та ін.] // Вісник СНАУ. - 2004.Випуск 7(12). - С. 91-94.

8. Оуен Р. Л. Иммуная активность птицы // Птицеводство. - 1996. - № 2. - С. 39-41. 